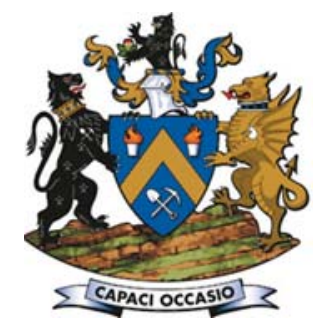

\title{
Thermodynamic analysis and experimental studies of magnesium extraction from szaibelyite-suanite ore by aluminium
}

\author{
by J.P. Peng*t, X.L. Wu* ${ }^{*}$, Y.Z. Di*†, N.X. Feng*t, and \\ S.G. Zhou*
}

\section{Synopsis}

Szaibelyite-suanite type ore is rich in magnesium oxide and boron oxide. We propose a new method to extract both metallic magnesium and valuable residues rich in boron by reduction using metallic aluminium.

Thermodynamic analysis of the reactions between aluminum and $\mathrm{MgO}, \mathrm{Mg}_{2} \mathrm{~B}_{2} \mathrm{O}_{5}$, and $\mathrm{Mg}_{3} \mathrm{~B}_{2} \mathrm{O}_{6}$ was carried out. The effects of $\mathrm{CaF}_{2}$ addition, temperature, mass of $\mathrm{Al}$, and pellet formation pressure on the extraction of magnesium were also investigated experimentally.

The results indicate that the magnesium oxide phase can be displaced from $2 \mathrm{MgO}-\mathrm{B}_{2} \mathrm{O}_{3}$ and $3 \mathrm{MgO} \cdot \mathrm{B}_{2} \mathrm{O}_{3}$ by $\mathrm{CaO}$ in the reduction system. The reduction ratio of magnesium oxide was $38 \%$ without calcium fluoride addition, increasing to $94 \%$ with $5.1 \%$ calcium fluoride. The reduction ratio increased with increasing temperature and mass of Al. To obtain a higher reduction ratio, the reduction pellet should be formed under a reasonable pressure.

Keywords

szaibelyite-suanite, magnesium, aluminum, thermodynamic analysis.

\section{Introduction}

Boron and its compounds are widely used in textiles, borosilicate glass, metallurgy, fertilizers, and nuclear shielding. Boron resources are mainly found in Turkey, the USA, Russia, and China. In Liaoning, China, there are abundant szaibelyite-suanite type ores that are rich in magnesium oxide and boron oxide. Szaibelyite and suanite ores are used to produce borax by a carbon dioxidesoda process. Annually, $2 \mathrm{Mt}$ of waste materials containing 3-20\% $\mathrm{B}_{2} \mathrm{O}_{3}$ and $2-25 \%$ $\mathrm{MgO}$ are produced during the process. It is necessary to make use of these waste materials containing high concentrations of boron oxide and magnesium oxide to avoid environmental problems as well as for economic reasons (Özdemir and K1pçak, 2007).

Many studies have been performed on boron recovery from boron-containing waste materials (Özdemir and K1pçak, 2007; Wang 2012; Özdemir and K1pçak, 2003). Some studies have focused on the preparation of magnesium sulphate, refractory materials, and fire retardants. Metallic magnesium can be extracted from borax sludge by vacuum thermal reduction (Wu et al., 2009). Boron oxide remains in the reduction residue, and thus the residue can be used to produce nonalkali glass fibre.

Szaibelyite-suanite type ores can be used to produce metallic magnesium using calcium carbide (Peng et al., 2011), metallic silicon (Wu et al., 2011), and metallic aluminum as reducing agents. Furthermore, the reduction residue also contains the main components of non-alkali glass fibre.

In this study, thermodynamic and experimental investigations of magnesium extraction by metallic aluminum were carried out.

\section{Raw materials}

The szaibelyite-suanite ore was supplied by the Kuandian boron-magnesium plant in Liaoning Province, China. Table I lists the chemical composition of the ore. Figure 1 shows a comparison of the X-ray diffraction (XRD) patterns of the ore before and after calcination. The XRD patterns show that the raw ore contains mainly $\mathrm{MgCO}_{3}, \mathrm{Mg}_{2} \mathrm{~B}_{2} \mathrm{O}_{5}$, and $\mathrm{MgBO}_{2}(\mathrm{OH})$. After calcination, the product consists of $\mathrm{MgO}, 2 \mathrm{MgO}^{\mathrm{a}} \mathrm{B}_{2} \mathrm{O}_{3}$, and $3 \mathrm{MgO} \cdot \mathrm{B}_{2} \mathrm{O}_{3}$.

Thermodynamic considerations

From a comparison of the XRD patterns (Figure 1), it is clear that $\mathrm{MgO}$ and $2 \mathrm{MgO} \cdot \mathrm{B}_{2} \mathrm{O}_{3}$ were generated through several important decomposition reactions during the calcination process:

* School of Material \& Metallurgy, Northeastern University, Shenyang, Liaoning, China.

+ Key Laboratory for Ecological Metallurgy of Multimetallic Mineral (Ministry of Education), Northeastern University, Shenyang, Liaoning, China.

¥ Xi'an University of Architecture and Technology, Xi'an, Shanxi, China.

(c) The Southern African Institute of Mining and Metallurgy, 2016. ISSN 2225-6253. Paper received Feb. 2013; revised paper received May 2016. 


\section{Thermodynamic analysis and experimental studies of magnesium extraction}

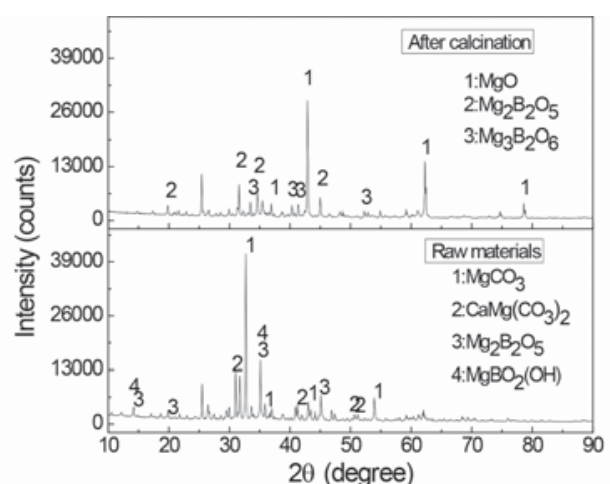

Figure 1-XRD patterns of the szaibelyite-suanite ore before and after calcination

Table I

Chemical composition of the szaibelyite-suanite ore used in this study (wt\%)

\begin{tabular}{|l|c|c|c|c|}
\hline $\mathrm{MgO}$ & $\mathrm{B}_{2} \mathrm{O}_{3}$ & $\mathrm{SiO}_{2}$ & $\mathrm{CaO}$ & $\mathrm{Al}_{2} \mathrm{O}_{3}$ \\
\hline 44.67 & 26.08 & 6.18 & 3.19 & 1.43 \\
\hline
\end{tabular}

$$
\begin{aligned}
& \mathrm{MgCO}_{3}=\mathrm{MgO}+\mathrm{CO}_{2} \\
& \mathrm{CaMg}\left(\mathrm{CO}_{3}\right)_{2}=\mathrm{MgO}+\mathrm{CaCO}_{3}+\mathrm{CO}_{2} \\
& 2 \mathrm{MgBO}_{2}(\mathrm{OH})=2 \mathrm{MgO} \cdot \mathrm{B}_{2} \mathrm{O}_{3}+\mathrm{H}_{2} \mathrm{O}
\end{aligned}
$$

The $\mathrm{CaCO}_{3}$ generated from Equation [2] decomposes at high temperatures:

$$
\mathrm{CaCO}_{3}=\mathrm{CaO}+\mathrm{CO}_{2}
$$

The existence of $3 \mathrm{MgO} \cdot \mathrm{B}_{2} \mathrm{O}_{3}$ proves that a reaction between $\mathrm{MgO}$ and $2 \mathrm{MgO} \cdot \mathrm{B}_{2} \mathrm{O}_{3}$ occurred:

$$
2 \mathrm{MgO} \cdot \mathrm{B}_{2} \mathrm{O}_{3}+\mathrm{MgO}=3 \mathrm{MgO} \cdot \mathrm{B}_{2} \mathrm{O}_{3}
$$

According to Hauck and Muller (1979), the formation of $3 \mathrm{MgO} \cdot \mathrm{B}_{2} \mathrm{O}_{3}$ occurs easily at high temperatures, and the standard Gibbs free energy $\Delta G^{0}$ (in kJ mol-1) for Equation [5] can be calculated by

$$
\Delta G_{5}^{0}=-7.4-33.27 \times 10^{-3} \mathrm{~T}
$$

Based on thermochemical data (Liang and Che, 1993), thermodynamic analysis of the reduction of magnesium oxide by aluminum proceeds as follows:

$$
\begin{aligned}
& 3 \mathrm{MgO}(\mathrm{s})+2 \mathrm{Al}(\mathrm{l})=3 \mathrm{Mg}(\mathrm{g})+\mathrm{Al}_{2} \mathrm{O}_{3}(\mathrm{~s}) \\
& \Delta G^{0}=509.08-0.2911 T \quad(1363-2000 \mathrm{~K}) \\
& 4 \mathrm{MgO}(\mathrm{s})+2 \mathrm{Al}(\mathrm{l})=3 \mathrm{Mg}(\mathrm{g})+\mathrm{MgO} \cdot \mathrm{Al}_{2} \mathrm{O}_{3}(\mathrm{~s}) \\
& \Delta G^{0}=478.27-0.2958 T \quad(1363-2000 \mathrm{~K}) \\
& 3\left(\mathrm{MgO} \cdot \mathrm{Al}_{2} \mathrm{O}_{3}\right)(\mathrm{s})+2 \mathrm{Al}(\mathrm{l})=3 \mathrm{Mg}(\mathrm{g})+4 \mathrm{Al}_{2} \mathrm{O}_{3}(\mathrm{~s}) \\
& \Delta G^{0}=601.5-0.277 T \quad(1363-2000 \mathrm{~K})
\end{aligned}
$$

For $2 \mathrm{MgO} \mathrm{B}_{2} \mathrm{O}_{3}$ and $3 \mathrm{MgO} \mathrm{B} \mathrm{O}_{3}$, we first consider the following possible reactions:

$$
\begin{aligned}
& 3\left(2 \mathrm{MgO} \cdot \mathrm{B}_{2} \mathrm{O}_{3}\right)(\mathrm{s})+4 \mathrm{Al}(\mathrm{l})=6 \mathrm{Mg}(\mathrm{g})+3 \mathrm{~B}_{2} \mathrm{O}_{3}(\mathrm{l})+2 \mathrm{Al}_{2} \mathrm{O}_{3} \\
& \Delta G^{0}=1436.96-0.594 T \\
& 3 \mathrm{MgO} \cdot \mathrm{B}_{2} \mathrm{O}_{3}(\mathrm{~s})+2 \mathrm{Al}(\mathrm{l})=3 \mathrm{Mg}(\mathrm{g})+\mathrm{B}_{2} \mathrm{O}_{3}(\mathrm{l})+\mathrm{Al}_{2} \mathrm{O}_{3}(\mathrm{~s}) \\
& \Delta G^{0}=656.08-0.2618 \mathrm{~T}
\end{aligned}
$$

The relationships between equilibrium magnesium partial pressure and temperature calculated from Equations [6], [7], [8], [9], and [10] are plotted in Figure 2. From Figure 2, it is evident that reaction [7] easily takes place because its critical reaction temperature is lower than that of reaction [6] under the same magnesium partial pressure. At temperatures below $2000 \mathrm{~K}$, the Gibbs free energy change of reaction [8] is positive.

The boiling point of magnesium $(1363 \mathrm{~K})$ is lower than that of aluminum $(2723 \mathrm{~K})$. When the magnesium produced is removed as vapour, reactions [6] and [7] can be accelerated. In addition, reaction [8] can also occur when the equilibrium magnesium partial pressure is decreased, as shown in Figure 2. Hong et al. (1999) and Yang et al. (2006) proposed that the reduction of magnesium oxide by aluminum should take place in two stages: reaction [7] to produce magnesium vapour and $\mathrm{MgO} \cdot \mathrm{Al}_{2} \mathrm{O}_{3}$ spinel and reduction (reaction [8]) of the spinel by aluminum.

However, Figure 2 indicates that the equilibrium partial pressures of magnesium for reactions [9] and [10] are less than 10-3 atm. below $1500 \mathrm{~K}$. Thus, it is difficult to directly extract magnesium from $2 \mathrm{MgO} \cdot \mathrm{B}_{2} \mathrm{O}_{3}$ and $3 \mathrm{MgO} \cdot \mathrm{B}_{2} \mathrm{O}_{3}$.

We propose to add $\mathrm{CaCO}_{3}$ into the reduction system, which is converted to $\mathrm{CaO}$ at high temperatures, because some reactions between $\mathrm{CaO}$ and $\mathrm{B}_{2} \mathrm{O}_{3}$ can easily take place (Turkdogan, 1980):

$$
\begin{aligned}
& \mathrm{CaO}(\mathrm{s})+\mathrm{B}_{2} \mathrm{O}_{3}(\mathrm{l})=\mathrm{CaO} \cdot \mathrm{B}_{2} \mathrm{O}_{3}(\mathrm{~s}) \\
& \Delta G^{0}=-149.4+30.96 \times 10^{-3} T \quad(723-1433 \mathrm{~K}) \\
& 2 \mathrm{CaO}(\mathrm{s})+\mathrm{B}_{2} \mathrm{O}_{3}(\mathrm{l})=2 \mathrm{CaO} \cdot \mathrm{B}_{2} \mathrm{O}_{3}(\mathrm{~s}) \\
& \Delta G^{0}=-208.8+17.15 \times 10^{-3} T(723-1583 \mathrm{~K}) \\
& 3 \mathrm{CaO}(\mathrm{s})+\mathrm{B}_{2} \mathrm{O}_{3}(\mathrm{l})=3 \mathrm{CaO} \cdot \mathrm{B}_{2} \mathrm{O}_{3}(\mathrm{~s}) \\
& \Delta G^{0}=-278.2+29.7 \times 10^{-3} T(723-1763 \mathrm{~K})
\end{aligned}
$$

Therefore, in the reduction system with $\mathrm{CaO}$, we consider the following reactions:

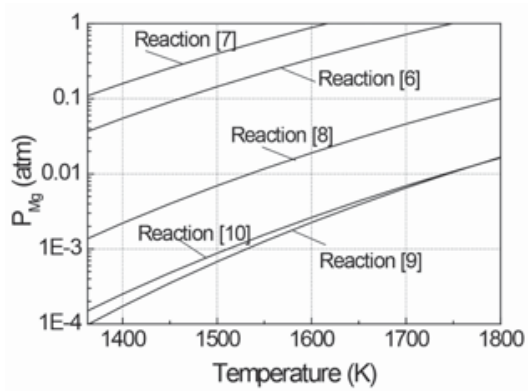

Figure 2-Effect of temperature on the equilibrium partial pressure of magnesium 


\section{Thermodynamic analysis and experimental studies of magnesium extraction}

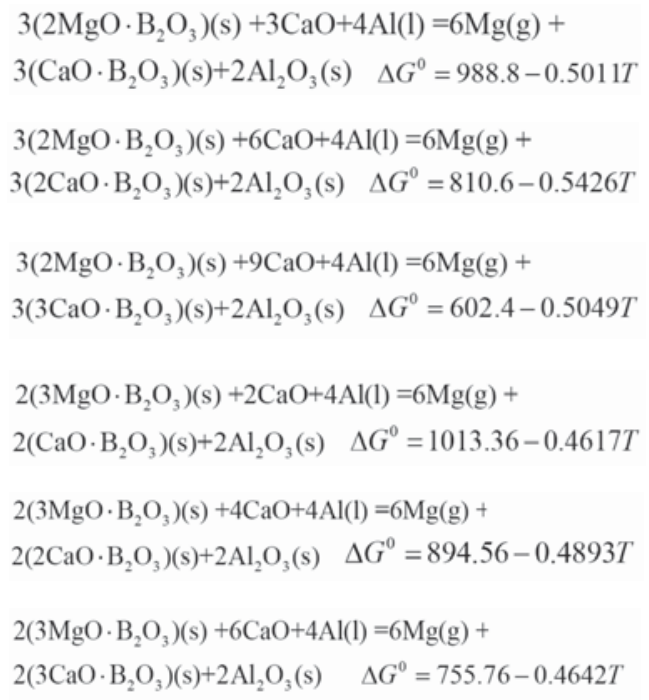

Figure 3 shows the relationships between equilibrium magnesium partial pressure and temperature calculated from Equations [14]-[19].

It is clear from Figure 3 that reaction [16] is most likely to occur because it has the highest equilibrium partial pressure of magnesium vapour. In addition, the figure shows that the equilibrium partial pressures of magnesium for reactions [14]-[19] are higher than $0.01 \mathrm{~atm}$. at $1500 \mathrm{~K}$; i.e., these reduction reactions with $\mathrm{CaO}$ could easily occur under vacuum conditions.

\section{Experimental procedure and apparatus}

Figure 4 shows a flow diagram of the experimental procedure. First, szaibelyite-suanite powder of less than $125 \mu \mathrm{m}$ in size and $\mathrm{CaCO}_{3}$ were mixed prior to compaction into briquettes. The briquettes were calcined at $1273 \mathrm{~K}$ for 30 minutes in a resistance furnace to eliminate $\mathrm{H}_{2} \mathrm{O}$ and $\mathrm{CO}_{2}$.

The calcined products were then ground into powder of particle size less than $120 \mu \mathrm{m}$. A homogeneous mixture of the calcined product powder and aluminum powder was compacted into pellets $27 \mathrm{~mm}$ in diameter and about $10 \mathrm{~mm}$ in thickness. Pellet samples were then fed into a retort fitted with a condenser to collect metallic magnesium. The retort was heated to a given experimental temperature and held at this temperature for a given period. The pressure in the retort was controlled by a vacuum system. Figure 5 shows a photograph of the apparatus and a schematic diagram of the retort.

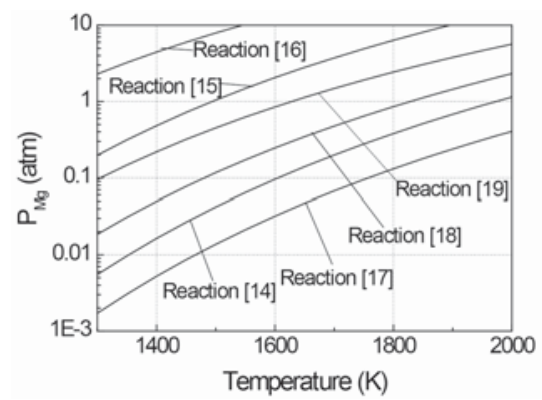

Figure 3-Effect of temperature on the equilibrium partial pressure of magnesium in reaction systems with $\mathrm{CaO}$
In the present study, experiments were performed at various operation conditions to study the effects of $\mathrm{CaF}_{2}$ addition, temperature, and pellet formation pressure on the reduction ratio of magnesium oxide. In general, the pellet mass was $130-150 \mathrm{~g}$.

\section{Results and discussion}

Table II lists the experimental conditions and results of the reduction experiments.

In Table II, the reduction ratio of magnesium oxide is used to estimate the level of the reduction process. It is defined as the ratio between the mass of magnesium extracted and the initial magnesium mass in the pellet used for reduction:

$$
S=\left(m_{0}-m_{1}\right) / m^{*} \times 100 \%
$$

where $m_{0}$ is the pellet mass before reduction, $m_{1}$ is the mass of the residue after reduction, and $m^{*}$ is the mass of magnesium contained in the pellet.

If only magnesium vapour is released from the pellet, the change in the pellet mass is taken as the mass of magnesium extracted. In fact, the magnesium products contained a low level of calcium. At high temperatures, calcium oxide in the pellet would also react with aluminum and form metallic calcium. Nevertheless, most of the metallic calcium would rapidly displace magnesium and form calcium oxide (Liang and Che, 1993):

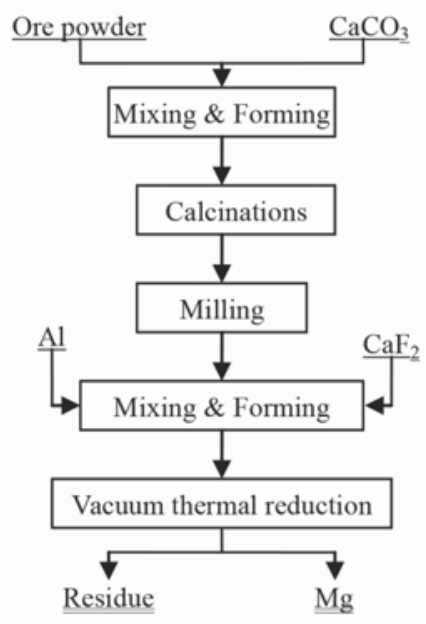

Figure 4-Flow diagram of the experiments
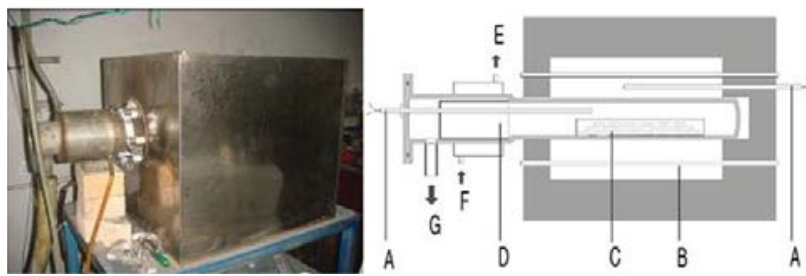

Figure 5-Apparatus for the vacuum thermal reduction experiments. (A) Thermocouple, (B) heating elements, (C) pellets, (D) condenser, (E) water outlet, (F) water inlet, (G) to vacuum 


\section{Thermodynamic analysis and experimental studies of magnesium extraction}

Table /l

Reduction ratios for experiments at various conditions

\begin{tabular}{|c|c|c|c|c|c|c|c|c|}
\hline & Ore (g) & $\mathrm{CaCO}_{3}(\mathrm{~g})$ & Al (g) & $\mathrm{CaF}_{2}(\mathrm{~g})$ & Pelletizing pressure (MPa) & Temperature (K) & Holding time $e^{*}(\min )$ & Reduction ratio (\%) \\
\hline M-1 & 80 & 110 & 35 & 0 & 90 & 1473 & 0 & 16 \\
\hline$M-2$ & 80 & 110 & 35 & 0 & 90 & 1473 & 30 & 39 \\
\hline M-3 & 80 & 110 & 35 & 0 & 90 & 1473 & 60 & 50 \\
\hline M-4 & 80 & 110 & 35 & 0 & 90 & 1473 & 90 & 78 \\
\hline M-5 & 80 & 110 & 35 & 0 & 90 & 1473 & 120 & 94 \\
\hline C-1 & 80 & 110 & 18.3 & 0 & 90 & 1473 & 120 & 38 \\
\hline C-2 & 80 & 110 & 18.3 & 3.5 & 90 & 1473 & 120 & 58 \\
\hline $\mathrm{C}-3$ & 80 & 110 & 18.3 & 4.1 & 90 & 1473 & 120 & 74 \\
\hline C-4 & 80 & 110 & 18.3 & 5.1 & 90 & 1473 & 120 & 94 \\
\hline C-5 & 80 & 110 & 18.3 & 5.3 & 90 & 1473 & 120 & 92 \\
\hline $\mathrm{T}-1$ & 80 & 151 & 18.3 & 5.1 & 90 & 1273 & 120 & 3 \\
\hline T-2 & 80 & 151 & 18.3 & 5.1 & 90 & 1323 & 120 & 15 \\
\hline T-3 & 80 & 151 & 18.3 & 5.1 & 90 & 1373 & 120 & 30 \\
\hline $\mathrm{T}-4$ & 80 & 151 & 18.3 & 5.1 & 90 & 1423 & 120 & 55 \\
\hline T-5 & 80 & 151 & 18.3 & 5.1 & 90 & 1473 & 120 & 95 \\
\hline$A-1$ & 80 & 110 & 16.6 & 5.1 & 90 & 1473 & 120 & 85 \\
\hline A-2 & 80 & 110 & 17.0 & 5.1 & 90 & 1473 & 120 & 88 \\
\hline$A-3$ & 80 & 110 & 17.5 & 5.1 & 90 & 1473 & 120 & 89 \\
\hline A-4 & 80 & 110 & 17.9 & 5.1 & 90 & 1473 & 120 & 92 \\
\hline A-5 & 80 & 110 & 18.3 & 5.1 & 90 & 1473 & 120 & 94 \\
\hline $\mathrm{F}-1$ & 80 & 110 & 18.3 & 5.1 & 0 & 1473 & 120 & 83 \\
\hline F-2 & 80 & 110 & 18.3 & 5.1 & 45 & 1473 & 120 & 89 \\
\hline $\mathrm{F}-3$ & 80 & 110 & 18.3 & 5.1 & 90 & 1473 & 120 & 94 \\
\hline $\mathrm{F}-4$ & 80 & 110 & 18.3 & 5.1 & 135 & 1473 & 120 & 91 \\
\hline$F-5$ & 80 & 110 & 18.3 & 5.1 & 180 & 1473 & 120 & 88 \\
\hline
\end{tabular}

${ }^{\star}$ The holding time was recorded from when the temperature reached the required experimental temperature.

$$
\begin{aligned}
& \mathrm{Ca}(\mathrm{l})+\mathrm{MgO}(\mathrm{s})=\mathrm{CaO}(\mathrm{s})+\mathrm{Mg}(\mathrm{g}) \\
& \Delta G^{0}=92.55-97.42 \times 10^{-3} \mathrm{~T}
\end{aligned}
$$

Hence, a very small amount of calcium is released from the pellet. The change in the pellet mass is taken as the mass of magnesium vapour because the mass of calcium is ignored. The error is likely to be less than $2 \%$.

\section{Role of $\mathrm{CaCO}_{3}$ addition}

An additional experiment was performed to study the behaviour of $\mathrm{CaO}$ during the calcination process. The material mixture consisted of $80.00 \mathrm{~g}$ ore powder and $151.10 \mathrm{~g}$ lime. The briquettes were formed under a pressure of $135 \mathrm{MPa}$ for 2 minutes and were then calcined at $1273 \mathrm{~K}$ for 30 minutes.

Figure 6 shows XRD patterns of the mixed material after calcination. The products contained $\mathrm{CaO}, \mathrm{MgO}$, and $\mathrm{Ca}_{3} \mathrm{~B}_{2} \mathrm{O}_{6}$. Comparison with the components of the raw ore after calcination (see Figure 1) indicates that the following reactions occurred during the calcination process:

$$
\begin{aligned}
& 2 \mathrm{CaO}(\mathrm{s})+2 \mathrm{MgO} \cdot \mathrm{B}_{2} \mathrm{O}_{3}(\mathrm{~s})=2 \mathrm{CaO} \cdot \mathrm{B}_{2} \mathrm{O}_{3}(\mathrm{~s})+2 \mathrm{MgO}(\mathrm{s}) \\
& \Delta G^{0}=-69.2+13.22 \times 10^{-3} \mathrm{~T} \\
& \mathrm{CaO}(\mathrm{s})+2 \mathrm{CaO} \cdot \mathrm{B}_{2} \mathrm{O}_{3}(\mathrm{~s})=3 \mathrm{CaO} \cdot \mathrm{B}_{2} \mathrm{O}_{3}(\mathrm{~s}) \\
& \Delta G^{0}=-69.4+12.55 \times 10^{-3} \mathrm{~T} \\
& 3 \mathrm{CaO}(\mathrm{s})+3 \mathrm{MgO} \cdot \mathrm{B}_{2} \mathrm{O}_{3}(\mathrm{~s})=3 \mathrm{CaO} \cdot \mathrm{B}_{2} \mathrm{O}_{3}(\mathrm{~s})+3 \mathrm{MgO}(\mathrm{s}) \\
& \Delta G^{0}=-131.2+59.04 \times 10^{-3} \mathrm{~T}
\end{aligned}
$$

Thus, the magnesium oxide phase is displaced from $2 \mathrm{MgO} \cdot \mathrm{B}_{2} \mathrm{O}_{3}$ and $3 \mathrm{MgO} \cdot \mathrm{B}_{2} \mathrm{O}_{3}$ by $\mathrm{CaO}$ to form $2 \mathrm{CaO} \cdot \mathrm{B}_{2} \mathrm{O}_{3}$ and $3 \mathrm{CaO} \cdot \mathrm{B}_{2} \mathrm{O}_{3}$. Therefore, magnesium can be extracted from szaibelyite-suanite ore by the addition of $\mathrm{CaCO}_{3}$.

\section{Effect of $\mathrm{CaF}_{2}$ addition on the reaction}

The Pidgeon process is the main method of magnesium metal production. In the process, calcium fluoride is added to the mixture of calcined dolomite and FeSi to improve the reduction ratio of magnesium oxide. In this study, a small amount of $\mathrm{CaF}_{2}$ was also added into the mixture (see Figure 4). The effect of $\mathrm{CaF}_{2}$ addition on the reduction ratio is shown in Table II.

For experiment $\mathrm{C}-1$ without $\mathrm{CaF}_{2}$, the reduction ratio of magnesium oxide is lower than for the experiments with $\mathrm{CaF}_{2}$ under the same conditions. Figure 7 shows XRD patterns of the reduced residue from $\mathrm{C}-1$. The chemical compositions of the residues from experiments $\mathrm{C}-1$ and $\mathrm{C}-4$ are listed in Table III. The residues contain mainly $3 \mathrm{CaO} \cdot \mathrm{B}_{2} \mathrm{O}_{3}$, $12 \mathrm{CaO} \cdot 7 \mathrm{Al}_{2} \mathrm{O}_{3}$, spinel $\left(\mathrm{MgO} \cdot \mathrm{Al}_{2} \mathrm{O}_{3}\right), \mathrm{MgO}$, and $\mathrm{Al}$. The existence of spinel proves that reaction [7] occurred. Calcium aluminate $\left(12 \mathrm{CaO} \cdot 7 \mathrm{Al}_{2} \mathrm{O}_{3}\right)$ forms by the reaction between calcium oxide and alumina:

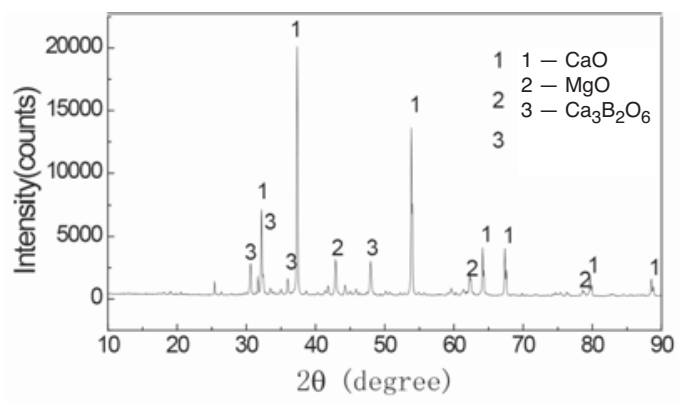

Figure 6-XRD patterns of the mixed material after calcination at 1273 $\mathrm{K}$ for $\mathbf{3 0}$ minutes 


\section{Thermodynamic analysis and experimental studies of magnesium extraction}

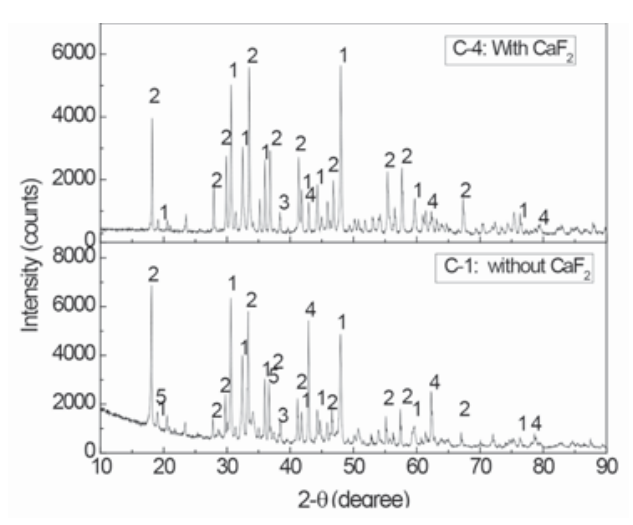

Figure 7-XRD patterns of the reduction residues from experiments $\mathrm{C}$ 1 and C-4. (1) $\mathrm{Ca}_{3} \mathrm{~B}_{2} \mathrm{O}_{6}$, (2) $\mathrm{Ca}_{12} \mathrm{Al}_{14} \mathrm{O}_{33}$, (3) Al, (4) $\mathrm{MgO}$, and (5) $\mathrm{MgAl}_{2} \mathrm{O}_{4}$

\begin{tabular}{|c|c|c|c|c|c|c|}
\hline \multicolumn{7}{|c|}{$\begin{array}{l}\text { Chemical compositions of the reduction residues } \\
\text { (wt\%) }\end{array}$} \\
\hline & MgO & $\mathrm{B}_{2} \mathrm{O}_{3}$ & $\mathrm{SiO}_{2}$ & $\mathrm{CaO}$ & $\mathrm{Al}+\mathrm{Al}_{2} \mathrm{O}_{3}$ & Others \\
\hline $\begin{array}{l}\text { C-1 } \\
\text { C-4 }\end{array}$ & $\begin{array}{r}16.72 \\
3.49\end{array}$ & $\begin{array}{l}14.52 \\
14.7\end{array}$ & $\begin{array}{l}3.2 \\
3\end{array}$ & $\begin{array}{l}52.04 \\
56.42\end{array}$ & $\begin{array}{l}13.07 \\
21.89\end{array}$ & $\begin{array}{l}0.45 \\
0.5\end{array}$ \\
\hline
\end{tabular}

$$
\begin{aligned}
& 12 \mathrm{CaO}+7 \mathrm{Al}_{2} \mathrm{O}_{3}=12 \mathrm{CaO} \cdot 7 \mathrm{Al}_{2} \mathrm{O}_{3} \\
& \Delta G^{\theta}=-6.56-0.222 \mathrm{~T}
\end{aligned}
$$

The formation of $12 \mathrm{CaO} \cdot 7 \mathrm{Al}_{2} \mathrm{O}_{3}$ favours the reduction of $\mathrm{MgO}$ by aluminum, and the following reaction takes place:

$$
\begin{aligned}
& 12 \mathrm{CaO}(\mathrm{s})+21 \mathrm{MgO}(\mathrm{s})+14 \mathrm{Al}(\mathrm{l})=21 \mathrm{Mg}(\mathrm{g})+ \\
& 12 \mathrm{CaO} \cdot 7 \mathrm{Al}_{2} \mathrm{O}_{3}(\mathrm{~s}) \quad \Delta G^{\theta}=3557-2.26 \mathrm{~T}
\end{aligned}
$$

However, for experiment $\mathrm{C}-1$, the high content of $\mathrm{MgO}$ in the residue verifies that the reduction ratio of magnesium oxide is low. The experimental results in Table II show that the reduction ratio of magnesium oxide increases markedly with increasing amounts of $\mathrm{CaF}_{2}$, reaching $94 \%$ in experiment $\mathrm{C}-4$.

Figure 7 also shows XRD patterns of the reduction residue from experiment $\mathrm{C}-4$. Compared with the patterns of the residue obtained from experiment $\mathrm{C}-1$, the XRD peaks of $\mathrm{MgAl}_{2} \mathrm{O}_{4}, \mathrm{MgO}$, and $\mathrm{Al}$ for experiment $\mathrm{C}-4$ are less intense. Thus, reactions [6] and [8] occurred.

\section{Effect of temperature on the reaction}

Table II also lists the results for experiments performed at various temperatures. The experimental temperatures were set to $1273-1473 \mathrm{~K}$, which are higher than the melting point of pure aluminum in ambient atmosphere ( $933 \mathrm{~K}$ ). Molten aluminum in the briquettes easily penetrates into the magnesium oxide phase. Furthermore, molten aluminum favours mass and heat transfer. Thus, the reaction between aluminum and magnesium oxide easily occurs.
The results show a remarkable improvement in the reduction ratio with increasing temperature. For experiment $\mathrm{T}-1$ carried out at $1273 \mathrm{~K}$, the reduction ratio is very poor. At a temperature of $1373 \mathrm{~K}$ (experiment $\mathrm{T}-3$ ), the reduction ratio of magnesium oxide increases to about $30 \%$. With increasing temperature, both the penetration rate of molten aluminum and the rate of release of magnesium vapour increase, so the reduction of $\mathrm{MgO}$ by $\mathrm{Al}$ is faster. At a temperature of $1473 \mathrm{~K}$ (experiment $\mathrm{T}-5$ ), the reduction ratio is $95 \%$, which is the highest reduction ratio achieved in the present study. Nevertheless, it must be pointed out that $151 \mathrm{~g}$ of calcium carbonate was used in experiment T-5. Under the same operation conditions, experiment C-4 achieved a $94 \%$ reduction ratio using only $110 \mathrm{~g}$ calcium carbonate (see Table II). Thus, experiment C-4 is considered more economical than experiment T-5.

\section{Effect of the reactant stoichiometry on the reaction}

According to Equation [7], the maximum reduction ratio of $\mathrm{MgO}$ is $75 \%$ because of the formation of $\mathrm{MgO} \cdot \mathrm{Al}_{2} \mathrm{O}_{3}$. If all of the $\mathrm{MgO} \cdot \mathrm{Al}_{2} \mathrm{O}_{3}$ reacts with $\mathrm{Al}$ to form $\mathrm{Mg}$ and $\mathrm{Al}_{2} \mathrm{O}_{3}$ (Equation [8]), the maximum reduction ratio of $\mathrm{MgO}$ is $100 \%$. The molar ratio of $\mathrm{Al}: \mathrm{MgO}$ must be higher than 2:3.

According to the chemical composition of the szaibelyitesuanite ore (Table I), $80 \mathrm{~g}$ of the ore contains $35.74 \mathrm{~g}$ of $\mathrm{MgO}$, therefore the stoichiometric requirement of $\mathrm{Al}$ is 16.08 g. Figure 8 shows the results of experiments with various amounts of aluminum. With increasing amounts of aluminum, the contact area of $\mathrm{MgO}$ with aluminum particles increases and thus the reduction ratio of magnesium oxide improves.

\section{Effect of pelletizing pressure on the reaction}

The effect of the pelletizing pressure on the reaction is shown in Figure 9. For experiment F-1, the uncompacted material was fed directly into the retort for thermal reduction. The reduction ratio for experiment $\mathrm{F}-1$ is $80 \%$. By increasing the pelletizing pressure to $90 \mathrm{MPa}$, the contact area between aluminum and $\mathrm{MgO}$ increases, and thus the reduction ratio increases.

However, with increasing pelletizing pressure, the porosity of the pellet decreases. Lower porosity hinders the release of magnesium vapour and penetration by unreacted aluminum into the magnesium oxide phase. For this reason, the reaction rate slows and the reduction ratio decreases. Figure 9 shows that a reasonable pelletizing pressure is about $90 \mathrm{MPa}$.

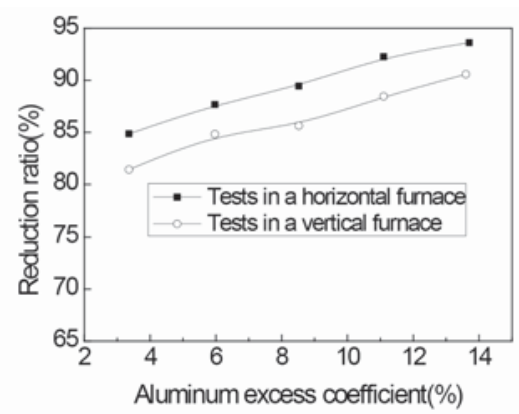

Figure 8-Effect of excess $\mathrm{Al}$ on the reduction ratio 


\section{Thermodynamic analysis and experimental studies of magnesium extraction}

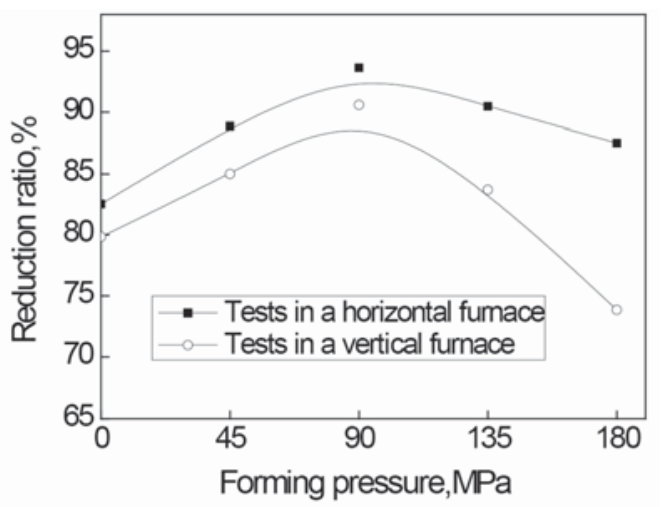

Figure 9-Effect of pelletizing pressure on the reduction ratio

\section{Conclusions}

Thermodynamic analysis of the reduction reactions of magnesium in $\mathrm{MgO}, \mathrm{Mg}_{2} \mathrm{~B}_{2} \mathrm{O}_{5}$, and $\mathrm{Mg}_{3} \mathrm{~B}_{2} \mathrm{O}_{6}$ by aluminum was carried out. The effects of $\mathrm{CaF}_{2}$, temperature, mass of $\mathrm{Al}$, and pelletizing pressure on the reduction ratio were also investigated experimentally. The following conclusions can be drawn.

(1) It is difficult to directly extract magnesium from $2 \mathrm{MgO} \cdot \mathrm{B}_{2} \mathrm{O}_{3}$ and $3 \mathrm{MgO} \cdot \mathrm{B}_{2} \mathrm{O}_{3}$. With $\mathrm{CaO}$ in the system, the magnesium oxide phase can be displaced from $2 \mathrm{MgO} \cdot \mathrm{B}_{2} \mathrm{O}_{3}$ and $3 \mathrm{MgO} \cdot \mathrm{B}_{2} \mathrm{O}_{3}$ due to the formation of $2 \mathrm{CaO} \cdot \mathrm{B}_{2} \mathrm{O}_{3}$ and $3 \mathrm{CaO} \cdot \mathrm{B}_{2} \mathrm{O}_{3}$. Thus, most of the magnesium in szaibelyite-suanite ores can be extracted under reasonable conditions

(2) The reduction of magnesium oxide by aluminum occurs in two stages: the reaction to produce magnesium vapour and $\mathrm{MgO} \cdot \mathrm{Al}_{2} \mathrm{O}_{3}$ and the reduction reaction between $\mathrm{MgO} \cdot \mathrm{Al}_{2} \mathrm{O}_{3}$ and aluminum under vacuum conditions. The formation of $12 \mathrm{CaO} \cdot 7 \mathrm{Al}_{2} \mathrm{O}_{3}$ favours the reduction of $\mathrm{MgO}$ by aluminum

(3) Calcium fluoride addition markedly improves the reduction ratio of magnesium oxide. The reduction ratio increases with increasing experimental temperature: from $3 \%$ at $1273 \mathrm{~K}$ to $95 \%$ at $1473 \mathrm{~K}$

(4) Increasing the pelletizing pressure up to $90 \mathrm{MPa}$ improves the reduction ratio from $83 \%$ (zero pressure) to $94 \%$. Further increases in pelletizing pressure decrease the porosity of the pellets, hindering the release of $\mathrm{Mg}$ vapour and thus slowing the rate and extent of the reaction.

\section{Acknowledgements}

This work was supported by a grant from the Fundamental Research Funds for the Central Universities (N100302009 and N150204013) and the National Natural Science Foundation of China (51304044).

\section{References}

Hauck, D. and Muller, F. 1979. Thermochemie des systems MgO- $\mathrm{B}_{2} \mathrm{O}_{3}$. Zeitschrift fur Physikalische Chemie Neue Folge, vol. 118. pp. 79-87.
Hong, L., OKUмURA, K., and SANo, M. 1999. Nonisothermal gravimetric investigation on kinetics of reduction of magnesia by aluminum. Metallurgical and Materials Transactions B, vol. 30B. pp.1003-1008.

LiAnG, Y.J. and CHE, Y.C. 1993. Handbook of Inorganic Thermodynamics. Northeastern University Press, Shenyang, China.

ÖZDEMIR, M. and K1PÇAK, I. 2003. Boron recovery from borax sludge, boron industrial waste, by solid-liquid extraction. Industrial and Engineering Chemistry Research, vol. 42. pp. 5256-5260.

ÖZDEMIR, M. and K1PçAK, I. 2007. Boron recovery from borax sludge using solid-liquid extraction followed by sorption with a boron selective resin in column. Environmental Progress, vol. 26, no. 4. pp. 375-383.

Peng, J.P., Wu, X.L., Feng, N.X., Zhou, S.G., and Wang, Z.H. 2011. Experimental study on vacuum thermal reduction of ascharite mineral with calcium carbide as reductant. Vacuum and Surface Engineering: Proceeding of the 10th International Conference on Vacuum Metallurgy. Ba, D.C. (ed.). Publishing House of Electronics Industry, Beijing. pp. 8-12.

TuRKDogan, E.T. 1980. Physical Chemistry of High Temperature Technology. Academic Press, New York, USA. pp. 7-8.

WANG, W.X. 2012. Technology of boron recovery from boron mud in boric acids production from low grade boron ore. Industrial Minerals \& Processing, vol. 41, no. 9. pp. 23-25.

Wu, X.L., Feng, N.X., Peng, J.P., and Wang, Y.W. 2009. Vacuum thermal extract magnesium from boron mud. Magnesium Technology 2009. Nyberg, E.A., Agnew, S.R., Neelameggham, N.R., and Pekguleryuz, M.O. (eds). The Minerals, Metals \& Materials Society, Warrendale, PA. pp. 61-63.

Wu, X.L., Feng, N.X., Peng, J.P., Wang, Z.H., and Cheng, E.Q. 2011. Experimental study on vacuum thermal reduction of ascharite mineral with silicon as reductant. Chinese Journal of Process Engineering, vol. 11, no. 4. pp. 294-298.

Yang, J., Kuwabara, M., SAwada, T., and SAno, M. 2006. Kinetics of isothermal reduction of $\mathrm{MgO}$ with Al. ISIJ International, vol. 46, no. 8. pp. 1130-1136. 